\title{
Epilepsy in Contemporary Fiction: Fates of Patients
}

\author{
Peter Wolf
}

\begin{abstract}
Fictional accounts of epilepsy are of interest because they may convey information on images and public views of epilepsy which are not contained in medical texts. Thus, medical and nonmedical traditions together form the cultural history of epilepsy. Of the numerous possible aspects of epilepsy in fiction, this paper looks especially at the writers'background of knowledge about epilepsy; epilepsy as a handicap and a reason for social rejection, with special reference to epilepsy under the Nazi rule; threats to patients'lives; the motive of the child with epilepsy as a divine child; and epilepsy as a fate, and a reason for distinction. Literary writers may help their readers understand that a person's suffering and fighting a condition like epilepsy very much deserves our attention and sympathy. Without being exclusive, the paper pays special attention to epilepsy in the writings of Canadian authors.
\end{abstract}

RÉSUMÉ: L'épilepsie dans le roman contemporain: le sort des patients. Les récits sur l'épilepsie dans la fiction sont intéressants parce qu'ils peuvent fournir de l'information sur les images et les visions du public sur l'épilepsie qu'on ne retrouve pas dans les textes médicaux. Les traditions médicales et non médicales forment l'histoire culturelle de l'épilepsie. Parmi les nombreux aspects possibles de l'épilepsie dans la fiction, cet article considère particulièrement les connaissances des auteurs sur l'épilepsie; l'épilepsie en tant que handicap et motif de rejet social en se référant particulièrement à l'épilepsie sous le régime Nazi; les menaces à la vie des patients; le thème de l'enfant épileptique comme un enfant divin; et l'épilepsie comme un sort et un motif de distinction. Les auteurs littéraires peuvent aider leurs lecteurs à comprendre qu'une personne qui souffre et qui combat une maladie comme l'épilepsie mérite notre attention et notre sympathie. Sans être exclusif, cet article accorde une attention spéciale à l'épilepsie dans les écrits des auteurs Canadiens.

Can. J. Neurol. Sci. 2000; 27: 166-172

Since the earliest historical times, in addition to medical writings, epilepsy has appeared in other texts, e.g. legal or literary. Medical and nonmedical traditions together form the cultural history of epilepsy and works of fiction may convey important information about images and public views of epilepsy which is not contained in medical textbooks. Therefore, epilepsy in fiction has, in recent years, received increasing attention. ${ }^{1,2,3} \mathrm{~A}$ related aspect is the growing emphasis which patients and their support groups put on their creativity and self-expression in the arts. This became clearly visible, for the first time, at the International Epilepsy Congress in Sydney, 1995, where a writers'workshop featured as part of the programme. ${ }^{4}$

Even brief references to epilepsy as a simile may tell us much about the attitudes of a writer or the public towards epilepsy. A list of epilepsy quotations from the works of Margaret Atwood alone (Table 1) is of great interest by its astonishing multiplicity of aspects. Other authors have dealt with epilepsy more extensively and the subject has been analyzed from many viewpoints such as images of epilepsy, ${ }^{1}$ images of doctors, ${ }^{5}$ experience and prejudice, ${ }^{6}$ and others. ${ }^{7}$

The fates of patients in fiction, however, are an aspect which has received little attention although the most comprehensive insight into an author's perception of epilepsy is probably given when he creates a character with epilepsy and gives some detail about this person's history and fate. There are several examples of this and it happens that some of these concern Canadian writers who figure prominently in this paper.

\section{THE WRITERS' BACKGROUND}

In some instances we know what made the author write about people with epilepsy. Thus, in Mary Jo Putney's romance "Dearly Beloved" (1990), a father and his son meet without knowing who they are. They build up an intense relationship because the father, who has led a very successful life in spite of having epilepsy, helps the son who also has seizures. He teaches his son to arrest them at the prodromal stage. Putney had become

From the Epilepsy Centre Bethel, Bielefeld, Germany.

RECEIVED JUNE 28, 1999. ACCEPTEDIN FINALFORMFEBRUAR Y 16, 2000.

Reprint requests to: $\mathrm{PW}$ olf, Epilepsie-Zentrum Bethel, Klinik für Anfallskranke, Mara 1, Maraweg 21, 33617 Bielefeld, Bethel, Germany 
interested in the subject because she had met various people with epilepsy and was impressed with their ways of coping with their condition and fighting it (personal communication).

British writer, Muriel Spark, once on an evening in the city, happened to observe a young man who had a convulsive seizure in the street in front of a pub. It seems that she was shocked by the experience but then began to wonder what the influence of seizures on the life of those afflicted could be. In her novel "The Bachelors" (1960), the central character Ronald, a naturally sociable young man, gradually turns into a loner because of his seizures. His friends become increasingly embarrassed and perplexed by him. A love affair fails when the girl becomes too patronizing in reaction to the seizures. The author's empathy is astonishingly accurate, particularly since she had never encountered anyone with this condition (personal communication).

The young German writer Arnold Stadler in "Mein Hund, meine Sau, mein Leben" (1994) tells the story of a young man who wants to be a Catholic priest but is denied ordination because he has a history of some faints, probably vasomotor syncope, which the bishop's medical advisor mistakes for epilepsy. Until a few years ago, a person with epilepsy was not accepted as a priest. A story like this had, in fact, happened to a close friend of Stadler (personal communication). The character in the book ends up making a good living as a hired speaker at burials.

A still closer relation is the background of New Zealand writer Janet Frame's epileptic characters. In her autobiography, she tells the story of her younger brother's epilepsy which began at the age of eight. In the first volume, "To the Is-Land" (1983), she describes how his first seizure in the night has a frightening input on the entire family. First the mother fetches the doctor's book and looks up "Convulsions". Then, "our brother had epilepsy, the doctor said, prescribing large doses of bromide which, combined with [his] now frequent attacks, or fits, as everyone called them, only increased his confusion and fear until each day at home there were episodes of violent rage when he attacked us or threw whatever was at hand to throw". Doctors advised putting the boy in an institution, which the mother fiercely resisted. In consequence, all kinds of magic cure are tried.

Frame's first novel, "Owls do Cry" (1957), ${ }^{8,9}$ uses freely transformed autobiographic material to a large extent. Thus, the seizure experience appears in poetic images:

"When he was sick his hand shook as if it felt cold and then a dark cloak would be thrown over his head by Jesus or God, and he would struggle inside the cloak, pushing at the velvet folds, waving his arms and legs in the air till the sun took pity, descending in a dazzling crane of light to haul, but, alas, preserve, where in all the sky, Toby wondered, this cloak of stifling recurring dream."

In this novel, there is a poor family with four children, one of whom is the boy Toby, who has epilepsy. He fights hard against the odds of poverty and illness and reaches a certain degree of independent living. He gets well enough to find work, have a driver's licence and get some money. He has a dream of travelling. Then he falls in love with a beauty who is far beyond his reach and turns into a loner and crank. In the final pessimistic vision of the children's fate that terminates the book, his forecast is: "Epileptic convicted for being a vagabond and lacking visible means of support."

In her novel "The Edge of the Alphabet" (1962), we find Toby again. Here he is one of three characters who meet on a ship sailing from New Zealand to England. He travels alone, in spite of epilepsy and a mild mental handicap. He gets a job but loses it again because he doesn't understand that some regular performance is expected from him. He leads the life as a loner and outsider. He wants to write a book "The Lost Tribe" but never gets it started. Many small details are given concerning the social implications of epilepsy. Here are a few quotations:

"When Toby was a child and his sisters were playing house and didn't want him for a husband because he might take a fit and spoil everything, spill the dock-seed tea and the dahlia wine, knock over the furniture and wet on the carpet, Toby learned to play by himself ..."

The aversion is not restricted to children. When Toby's aunt Norma is asked to put him up for a few days, it is said that "she did not want Toby. She did not want to associate with someone who was an epileptic; it was an embarrassing disease that had to be explained and excused and that caused people to wonder about the family history. Toby himself did not help either. She thought him uncouth and dull. His apparent slowness of thinking and his habit of taking such a long time to utter one sentence, and the way in which, once he began talking, he stayed doggedly on the same subject, ignoring the attempts of others to change it, all seemed to Norma like evidence of mental backwardness."

Fortunately, views other than aunt Norma's are encountered. It turns out, however, that Toby cannot easily shake the negative images he has grown up with. Thus, the doctor in London "who provides his pills" tries to give him different thoughts, telling him "about a Society of Epileptics where the sufferers met and talked to one another, worked out their problems, regained their sense of proportion ... or so the doctor said, adding fatuously, 'You're all human beings, you know; not epileptics, just human beings.' Toby was not so sure of that. He declined to join the Society."

It is also questionable how helpful it is for patients when they are told that some celebrities suffered from the same condition. It is their own condition they have to cope with and not that of other people.

"Sometimes at night he heard his mother's voice saying to him, 'Remember, Toby, Napoleon was an epileptic, many great men and leaders, Toby, had your trouble." Obviously his mother has often said this but it irritated, rather than comforted him.

At the end of this experience of "self-discovery" Toby returns, resigned, from London to New Zealand, to a life that he had hoped to leave for good.

Japanese Nobel Prize winner Kenzaburo Oe is yet another writer who has an intimate knowledge of epilepsy. His own son has it, along with moderate mental retardation. Oe's literary work is an extremely honest report and reflection of his own life including his rejection of the child at birth when the handicap became apparent. He then accepts this fate to experience the unique qualities and genuine goodness which the son develops, and indeed, which make him beloved by all his family. In his book "Quiet Life" (1990), the son is a young adult and in a threatening situation gives shelter to his younger sister who is 
supposed to take care of him in their parents'absence. His pure and candid simplicity makes him see through all sorts of disguises, not unlike the child in Hans Christian Andersen's wellknown fairy tale "The Emperor's New Clothes". Oe makes his readers understand that a handicapped person's being different does not mean a lesser, but a different value.

\section{EPILEPSY, HANDICAP AND REJECTION}

To understand the full depth of Oe's appreciation of the specific human value of his handicapped son, it needs to be seen against the background of the writer's initial willingness to let his newborn son die when it appeared that he had a major brain malformation, as he has disclosed in the radical self-scrutiny of his work "A Personal Matter". Together with the subsequent change of mind, this seems to have been a central cathartic experience in the writer's life.

We live in an era where euthanasia for severely mentally handicapped children is being publicly discussed. In Peter Nichols' play "A Day in the Death of Joe Egg" (1967), it is supported by a friend of the parents of a severely handicapped and epileptic child and there is a scene where the desperate father almost kills her. Another character, however, argues "thou shalt not kill. D'you know how the final solution of the Jewish problem began? In the mental hospitals. It's only a step from there to Auschwitz."

In fact, during the Nazi rule in Germany, the life of even moderately handicapped people was threatened. They were qualified as "useless eaters".

"She is epileptic and that is life not worth living" is what another child in the orphanage in Hubert Fichte's "Das Waisenhaus" (1965) says about Anna. "Life not worth living" was the formula with which the Nazis prepared the German people for the killing of mentally disturbed and handicapped persons. Fichte's book takes place, in the year of 1944, in a Bavarian orphange kept by Catholic nuns who give shelter to some outcast children. One of them, Detlev, from whose perspective the story is told, is from the north, a Protestant, and the illegitimate child of a Jewish father. The situation is autobiographic of Hubert Fichte and the character Anna is most probably the portrait of a real person. She suffers from absences and rare convulsions precipitated by intermittent light stimuli. One self-provoked seizure, by eye-blinking, is documented in the book. Detlev has to leave the orphanage after one year when the nuns cannot protect him any longer. Anna's fate is unknown.

Italian writer Elsa Morante's "La Storia" (1974) is situated in a comparable setting: Rome in the early 1940s, occupied by the German army. The three central characters of the novel, a mother and her two sons, all have epilepsy but their fates are different. The mother, Ida, is a small, frail, timid primary school teacher from a village in the south who never quite adapted to the life of the big city. Her seizures were frequent in her childhood but after puberty they became rare and are no big issue anymore. However, she is ridden by other anxieties: there is one Jewish ancestor; will she and her son become victims of the fascists? Her first son, Nino, is a sunny boy who easily finds his way through the dangers of the metropolis in war, starts as a fascist and then becomes a partisan. After the end of the war, he gets involved in black market activities and is killed in an encounter
Table 1: Epilepsy in the works of Margaret Atwood

\section{“Life Before Man" (1979)}

The otherworldly expression on the face of her suspected rival Lesje reminds Elizabeth of someone having a minor epileptic fit.

“The Salt Garden" (1983)

A young woman who develops faints beginning with complex visual hallucinations wonders whether these could be "borderline epileptic".

“The Handmaid's Tale" (1985)

A paroxysm of irresistable laughter is compared to an epileptic seizure.

\section{“Cat's Eye"(1989)}

In one of the most remarkable epilepsy metaphors of world literature, a sudden revelation of positive lifechanging significance is likened to being seized by an epileptic fit.

\section{“Alias Grace” (1996)}

1) A psychiatrist of 1851 mentions epilepsy as one of several organic causes of mental illness (historically correct) and knows the newly discovered bromide therapy of epilepsy.

2) A highly dramatic scene of seduction culminates when "she kisses his face all over; her movements become epileptic".

with the police. His epilepsy is very mild, restricted to a few absences now and then but it is mentioned.

Ida's pregnancy with the younger son Giuseppe, called Useppe, comes to some extent as a surprise to her. He is conceived when she is raped by a German soldier who mistakes the Grand mal seizure which she develops during the act - the first since many years - for a violent defense followed by orgasm. The seizure sweeps most of the event from her memory.

\section{THE CHILD WITH EPILEPSY - A DIVINE CHILD}

That a child is conceived without the mother's being aware, or fully aware of a sexual act with a man, is a typical part of legends of children of gods and there are several other indications that Useppe should be seen as a legendary, a divine child: ${ }^{10,11} \mathrm{He}$ has a remarkable, instinctive understanding of events normally beyond a child's grasp. Death and disaster cannot be concealed from him. He suffers when the world suffers but he can also understand the language of birds and dogs, and there is a shining around him which seems not to be from this world.

It may be recalled that Dostoyevsky, who himself had epilepsy, when he wrote his great novel "The Idiot" intended to create his epileptic character, Prince Myshkin, in the image of Christ.

In P.D. James' "The Children of Men" (1981) mankind is threatened by eradication because, by some mysterious reason or agent, children are no longer conceived and born anywhere. Then, the first child born after 25 years, the child-saviour on whom all the hopes of humanity rest, is the son of a mother who has a crippled hand and a father who had epilepsy. It is amazing 
how these legendary motives in the books of modern, secular writers revert to ancient beliefs that saw epilepsy as a "sacred" disease.

In Columbian writer Laura Restrepo's novel "Sweet Company" of 1996, an angel is said to have appeared in a poor quarter outside Bogotá. He is actually a young man with epilepsy, whose seizures are supposed to cause thunderstorms and other catastrophes. They can be provoked by intermittent lights and this sensitivity is used by the people who handle him. Apart from this pseudoreligious commerce, the young man is not only of unusual beauty but there is something in his appearance which elevates him beyond our everyday world and makes people believe in his angelic quality.

Returning once again to Elsa Morante's novel, Useppe develops seizures at an early age. He is investigated using an EEG, probably one of the first such machines existing in Italy. $\mathrm{He}$ is treated with phenobarbital which the mother administers quite irregularly. He dies in his sixth year of life in a status epilepticus. The mind of Ida, the mother, succumbs to this last of her disasters; she stops reacting to any external stimuli, remains always in the same posture, with an empty smile and dies after nine years in a mental institution.

Morante's book is not a realistic novel but, rather, a parable of the human condition which is subject to the blows of blind and cruel fate, and of the futility of human struggle against it. Still, it leaves us with the bright image of the child divine, a child with epilepsy.

\section{THREATS TO PATIENTS' LIVES}

The religious dimension of epilepsy in Christian societies may be related to the seizure as an image of death and resurrection. ${ }^{12}$ The first impression of unprepared observers of a generalised tonic-clonic seizure often is that the affected is about to die. Drowning and other accidents, status epilepticus and sudden unexplained death are the main causes of an increased mortality rate in epilepsy. These may be the reasons behind occasional notions of proximity of epilepsy and death. Thus, Hubert Aquin, a writer with epilepsy, in "Prochain Épisode" (1965) talks about the death of Byron, his alter ego as a poetguerilla, as the "final epilepsy of Missolunghi".

Also, in fiction, the lives of epileptic characters are threatened. Like Useppe, they may die from natural reasons related to the disease, or they may be killed. Consider what happens to the boy Owen in North Irish author's Bernard McLaverty's "Lamb" (1980). He comes from a socially impoverished family with a violent father and a mother who may once have tried to choke him and, following some petty thefts, he lives in a house of correction run by Catholic monks. One of these, young Brother Sebastian, takes a liking to Owen when he sees him brought into a dangerous situation by a seizure. Trying to replace his father, he runs away with him but is quite unable to handle the resulting problems. When he sees no way out, he remembers a talk where Owen has told him about a feeling of happiness which he experiences in his seizures: "It's a nice feeling. Everything is right. Everything is in its right place ... it's the right colour, the right smell. Sometimes I get a smell that ... It's beautiful ... The whole thing is ... beautiful. I ... I be happy. Just say ... I be that happy." ... "I would like to be like that all the time."

In what he sees as an act of pure and caring love, Sebastian
Table 2: People with epilepsy as victims in detective stories

\section{Killed or mortally threatened}

$\begin{array}{ll}\text { Patricia Cornwell } & \text { From Potter's Field } \\ \text { Tony Fennelly } & \text { Kiss Yourself Goodbye } \\ \text { Richard Pollak } & \text { The Episode } \\ \text { Georges Simenon } & \text { Le haut mal }\end{array}$

Scapegoats

Agatha Christie

The ABC Murders

The Murder on the Links

Tony Fennelly

The Closet Hanging

takes the boy to the seaside and provokes a seizure by replacing his antiepileptic drugs with other pills. He drowns the boy during the seizure, and then tries to drown himself but is unable to.

With its many layers of symbols and understandings, this is a well-written book. The misconception of love which destroys what one claims to love highest can be read as a metaphor of the fighting parties'attitudes in the writer's home country, Northern Ireland. It is a person with epilepsy who is disposed of in this story, becomes a mere object of another person's will, whim and misunderstanding. It is his illness which makes him defenseless.

Owen, in McLaverty's "Lamb" is the only fictitious epileptic character who is killed out of love, albeit misunderstood. The defenselessness of people with epilepsy makes them easy victims in detective stories. ${ }^{13}$ They may be killed (Patricia Cornwell, "From Potter's Field", Georges Simenon, "Le hHaut Mal") but they also are welcome as scapegoats on whom a crime can be hung (Table 2) because they have lapses of consciousness and memory (Agatha Christie, "The ABC Murders", Tony Fennelly, "The Closet Hanging") or both consequences can be combined (Fennelly, "Kiss Yourself Goodbye", Richard Pollak, "The Episode") because a dead man cannot defend himself against incrimination (Christie, "The Murder on the Links").

Yet another threat to a person with epilepsy is the possibility of accidents and here we return to Canadian literature. In Mordecai Richler's novel "The Apprenticeship of Duddy Kravitz" (1959), Duddy is a young man who develops a fantastic series of projects and businesses to reach his dream of acquiring his own property. He forms a small team with his girl, Yvette and then a young chap called Virgil. The latter suffers from epilepsy, with frequent convulsive seizures mostly, but not always, in his sleep. He knows he shouldn't drive a car but does it when it cannot be helped. One day Virgil makes a delivery with the truck, has a seizure, runs into a tree and becomes paraplegic.

Virgil has always had a dream to become a leader in what at the time, did not yet exist: a self-help movement for people with epilepsy. According to him, epileptics have nobody to defend them, to plead their case. They have a tendency to hide their condition to avoid prejudices. After his accident, he starts a mimeographed magazine "The Crusader. The Only Magazine in the World Published by Epileptics for Epileptics". Richler writes a 
whole issue of it, editorial, mailbox, ads, book review, special article, everything. It's a touching piece of amateurism, honest and pathetic. Virgil is very proud of it. According to him, the accident was "a blessing in disguise. ... If not for the accident there'd be no "Crusader". It might have taken me years to get going."

This is a very creative way of coping with what everyone else would have seen as the worst of possible disasters. As a contrast, in "Barney's Version" (1997) Richler adds another dimension of fatality to epilepsy when he gives the following biography in a nutshell: "Monsieur Henri ... was extremely polite. Very sophisticated. Introduce him to a lady and he would kiss her hand, without actually touching it. Then it turned out that his only son was an epileptic, and it broke his heart. He began to drink and his business went downhill." A person's fate depends to a large extent upon how he or she reacts to what life happens to have in store for them.

\section{FATE AND DISTINCTION}

Interestingly, books whose epileptic characters are based upon real persons, like the above by Kenzaburo Oe, tend to give much less pessimistic views about having epilepsy ${ }^{14}$ than some fiction. In Dutch writer Rosita Steenbeek's autobiographic novel "The Last Woman" (1994), the seizures are the sequelae of a spontaneous brain bleeding which inflicted the writer at age 13 . To have survived this catastrophic event made her radically change her views and attitudes towards life. The memory of her condition becomes a source of amazing vivacity and brio.

A side-effect of this attitude is a certain amount of noncompliance, as she is inclined to forget to renew her prescriptions which provokes some seizures.

I can only guess to what extent Margaret Gibson, another Canadian writer, uses autobiographic material in her "Opium Dreams" (1997). Maggie Glass, from whose perspective the story is told, experiences her father's decline with Alzheimer's, and re-lives the problematic story of their family where he and she are the dreamers and outsiders in relation to the aggressively normal mother and "Sisters Three". Both spent time in mental hospitals - the father following a breakdown on return from World War II, Maggie in a teenage crisis. In spite of one deep disappointment when she was raped and he did not stand by her, Maggie is the one who cares for him as he gets old and lives in a mental home with Alzheimer's.

The central theme of the book is Maggie's reconstruction of her own life in response to the experience of her father's decline. One of her problems is epilepsy caused, as it seems, by a head trauma with intracranial bleeding. The following passage is extensively quoted because it illustrates many aspects of the experience of having seizures particularly in the presence of others. It is also exemplary of how her experiences are integrated in the artistic whole of the story:

"There is something magical about epilepsy, some magic to cause that short, that sparking in the brain. Daddy never understood that, the magic lining beneath the illness.

He did not know how to greet me when I returned from the Country of Fugue - more than that, he seldom ever knew when I was entering that strange and eerie geography, that other realm where I imagine language is garbled and sleep only a dream rumoured of.
He had never woken me from my nightmares, which were frequent and loud when I lived at home. The next morning he'd comment, "Boy, you were having one bangup humdinger of a nightmare last night." When I asked him why he did not wake me he'd adjust his pipe in his mouth, or fiddle with a shirt button, or light the hundredth cigarette of the day and shrug, his eyes vague and disinterested.

Or, I would find myself suddenly "coming to" in the car with Daddy bent low behind the wheel, burning rubber, my nose pressed at an awkward angle against the window, sitting beside my father, my mother, her mouth grim, her purse held in front of her like a battleshield as they raced me to yet another hospital because of another seizure on nights that The Kid [her fatherless son] and I slept over. My brain would be filled up dangerously and sparking and emptying at the same time at a terrifying speed like a river being drained, auras sparking, dancing, eyes bulging so far out of their sockets that I felt they were going to pop out altogether. One doctor said to me at one hospital, "Your eyes are protruding like crazy." And promptly disappeared from the examining room.

At other times, oddly, he would react to a fit without even so much as a comment or a raised eyebrow. One such occasion was after I had a seizure in his car, the first of my seizures he'd ever witnessed. When it was over, after he'd pulled over to the side of the road and taken the cigarette from my hand and was assured it was all over and done with, he drove me in my shell-shocked state over to his house, where we ate a lunch of soft-boiled eggs and tiny triangles of buttered toast and then he drove me home to the slum without a word about the seizure.

Once, he drove me to a hospital Emergency and the doctor who had seen me, a doctor with a frizzy dark beard and thin, long brown hands said, "She had the jerking fit because she has a cold and is coughing." Clarice [the mother] made a face like she could spit, but Daddy said only later in a mild voice that he thought the doctor's diagnosis inadequate. "Because during it you rose five feet off the floor like a bird taking wing."

I was an epileptic. It was staring them more than rather dramatically in the face and yet they made no real attempt to define it or accept it for what it was. Epilepsy. That awful word. It was just the Dreamer dreaming crazy. It was not until three years later, after my parents had borne witness to many fits, that a good, kind doctor, whom I call Friend and All Mine, treated me for exhaustion and shattered nerves in hospital and became immediately suspicious of the blanks in my eyes. He set up tests for epilepsy, an EEG, and I was put on Valproic Acid then, a medication for epilepsy, although not as commonly known as Dilantin. This Famous-Friend Doctor, who is kind and all mine, is still my shrink. The Kid, who had been a witness to these seizures since he was four years old and terrified, and often thought back then that I was dying, was, even though tearful and weeping, more helpful and responsible than Daddy or Clarice ever were.

The Country of Fugue - where people exist, walk around, say things but know nothing of their presence in that country or what language they speak or that they speak at all, are unaware they are inhabitants at the time of such a place - was beyond Daddy. The Kid knew. He understood the magic inherent in the thing. Once, on half returning from that Country of Fugue, I suddenly found The Kid's small hand wrapped around mine, pulling me 
rapidly, rather frantically out of a smoke shop, and I heard a steady stream of curse words coming from a mouth (mine?) aimed at the startled Vietnamese proprietor, then The Kid saying, "Come on, Mom, you're at that Other Place."

Another time on just returning from the Country of Fugue, passport stamped, I found my eyes (mine again) looking at The Kid across the coffee table. He blinked and said, "You're back." God, he's a good kid.

Suddenly my head aches just from all these thoughts, thinking of the peculiar zeros in my father's and my mother's way of going along with the seizures, as if it were normal when they must have known it was not."

It seems that the treatment she gets is effective because epilepsy does not become a major problem but then we find Maggie working as a nurses' help at an institution called the "Halfway House for Epileptics and Other Shell-Shocked". Sharing the condition of epilepsy with the patients in the institution helps her understanding, and her ability to provide care for them. Here are a few snap-shots from her work to be juxtaposed to her own experiences: "Beth-Ann came lumbering over in her football helmet and said in her gravelly voice that she needed a car ticket. I told her I'd get one for her. Beth-Ann is a nice girl with a sweet, shy sense of humour. She is tall, big-boned and heavy-fleshed with tiny blue eyes, and has so many grand mals a day she has to wear a football helmet. 'It just feels bad, is all, just feels bad, is all,'she mutters to herself over and over, meaning the fireworks in her brain. There were others there too that I took care of to support my habit of writing poetry and short stories. ... Unlike the residents at the Halfway House for Epilep tics and Other Shell-Shocked, I didn't live there, I merely worked there to support my addiction to words."

We get a feeling that the situation helps Maggie with her own condition.

The last book to be discussed here is Canadian writer Timothy Findley's novel “The Piano Man's Daughter" (1995). Its main theme is the life and fate of one particular person, who happens to suffer from epilepsy. It is the story of a tragedy which makes us feel close to Lily, the piano man's daughter, a most loveable heroine. Fate in the ancient sense of the word is an irrevocable spell cast over man's life from its onset. In terms of modern science this could be translated into genetic determination. Lily has had a great uncle whom nobody talks about. He had epilepsy, became mentally ill and was made to live in an attic to which he set fire, burning both the house and himself. Lily develops seizures and is made to live in the attic after her having a seizure spoiled an evening reception at home. She begins to play with fire. At a later age she becomes mentally disturbed and lives in a mental home where she is killed in a fire which she may have set herself. Is this the fate which she inherited?

Could she have had a different life if she had received more love, had been better defended by her mother against her stepfather? But then, is anybody free in his or her decisions, could they have acted otherwise? There have been openings in this life. There were love affairs and, in consequence, there is a son, from whose perspective the story is told. He tells it as an attempt to reconstruct his mother's life but also to cope with a situation where he has failed in his filial love and disavowed her when she had a seizure in public.

There are many facets in this story that cannot be discussed here in any detail but which make it one of the most remarkable and most accurate accounts of epilepsy in literature. We hear about the attitudes which people of different backgrounds and stations in life take in relation to a person with epilepsy; about the emotional precipitation of seizures; about concealment of and coming out with the diagnosis; about the arrest of auras; about epilepsy as a handicap; about medical and even surgical treatment. There are metaphors of epilepsy as fire and as storms.

Findley, when he talks about the "Nemesis" in his heroine's life, clearly indicates that he saw this story as one of tragic fate, not of human guilt. Let us remember that a tragic fate for the ancient Greeks was a fate of greatness and distinction.

\section{CONCLUSIONS}

Fictional texts are an important contribution to the cultural history of epilepsy and works where the history and fate of a character with epilepsy is given in some detail are of special interest in this respect. It is not uncommon that such texts are based on some kind of specific personal experience.

Almost invariably, these accounts are concerned with these characters' coping with the disorder and defining their social roles and with the responses of their surroundings to their condition. These responses may be understanding and empathic but they may also be rejective, aggressive, and even lifethreatening. There is a clear notion, among several authors, that epilepsy is a condition that may mark the afflicted ones as possible victims of both consequences of the seizures as such, and the aggression of other people. At the same time, the fates of people with epilepsy, especially children and even with additional handicaps, are presented by some authors with unusual respect. They may help their readers understand that a person's suffering and fighting a condition like epilepsy deserves our attention and sympathy even if, or especially when, the fate eventually may be a tragic one.

Various Canadian writers including Hubert Aquin, Margaret Atwood, Timothy Findley, Margaret Gibson, and Mordecai Richler deserve to be mentioned for their distinguished contributions to this theme.

\section{REFERENCES}

1. Ozer IJ. Images of Epilepsy in Literature. Epilepsia 1991;32:198 209

2. Paladin AV. Epilepsy in Twentieth Century Literature. Epilepsia 1995;36:1058 - 1060

3. Wolf P. Epilepsy in Literature. Epilepsia 1995;36: Suppl. 1 S 12 - S 17.

4. Goss S (ed) Epilepsy - I can live with that! Writings by people with epilepsy. Epilepsy Foundation of Victoria, Camberwell, Victoria, 1995.

5. Wolf P. Epilepsy in Literature: Images of Doctors. In: Lüders HO. ed. Epileptic Seizures: Pathophysiology and Clinical Semiology. Philadelphia: Saunders, 2000 (in press).

6. Wolf P. Erfahrung und Vorurteil in literarischen Epilepsiedarstellungen. Fundament. Psychiat 1996;10:148-155.

7. Wolf P. Epilepsy in Literature: Catalogue and aspects. European Epilepsy Academy: http://www.eurepa.de.

8. v. Engelhardt D. Sinn und Bedeutung von Epilepsiemotiven in der Literatur. Epilepsie-Blätter 1996;9 Suppl. 1:9-18.

9. Wolf P. Epilepsie als Metapher in der zeitgenössischen Literatur. Epilepsie-Blätter 1994;7 Suppl. 2:31 - 35.

10. Schmidt L. Epilepsie als literarisches Motiv - Elsa Morantes Roman "La storia”. Epilepsie-Blätter 1990;3:7 - 12. 
11. v. Engelhardt D. Epilepsie in Elsa Morantes "La storia". EpilepsieBlätter 1994;7 Suppl 2:36 - 39.

12. Janz D. Epilepsy, Viewed Metaphysically: An Interpretation of the Biblical Story of the Epileptic Boy and of Raphael's Transfiguration. Epilepsia 1986;27:316 - 322.
13. Wolf P. Epilepsie und Verbrechen in der Literatur. Kranke als Täter und Opfer. Epilepsie-Blätter 1996;9: Suppl. 1 36-40.

14. Wolf P. Epilepsy in literature. To have epilepsy. International Epilepsy News Nr. 131, 1998;9.

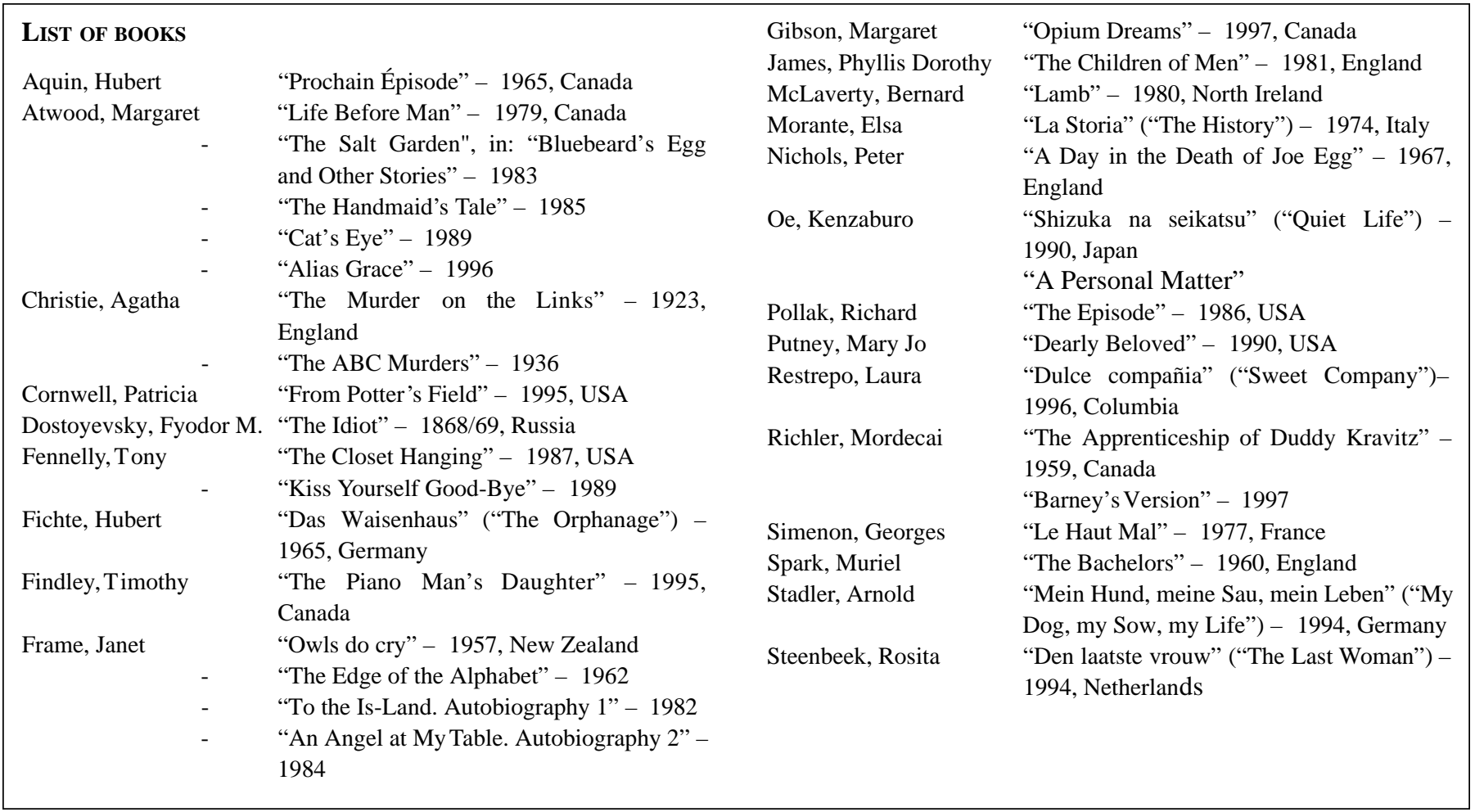

